\title{
Considerations on free public transport implementation - based on Krakow case
}

\section{Lidia Zakowska}

Dr. Eng. Prof., Cracow University of Technology, Faculty of Civil Engineering, Management in Building and Transport Institute, Section of Transport

Maciej Adam Piwowarczyk, Jan Hipolit Aleksandrowicz

MScEng, Cracow University of Technology, Faculty of Civil Engineering, Management in Building and Transport Institute, Section of Transport

\section{SUMMARY}

New transport philosophy follows the equity criteria and should also lead toward sustainability and equity in building policies of public transport in cities. Implementation of free public transport for citizens is widely considered in different countries, cities and on several administrative government levels. However, there are not may examples of successful implementation if this concept in Europe. This work presents the discussion on multi-dimensional barriers, which make implementation of equity criteria to transport policies difficult. Both advantages and disadvantages of free of charge public transport system are presented, based on current discussions, as well as on some European examples, case studies and scientific evaluations. The case study simulation for the Krakow urban area is initiated and described, testing the effects of free of charge public transport on economic and mobility factors. Considerations presented in this work are based on current challenges to build green with multimodal transport, respecting factors of economy, traffic volumes, safety and environmental factors. It is predicted that success of free public transport for citizens could create a significant shift in travel demand from private car use toward trams and busses, reducing accident costs, decreasing congestion in city centers and limiting air pollution, contributing to social and economic growth of the whole metropolitan area.

\section{INTRODUCTION}

Free of charge to citizens public transport, financed from the local government sources, has been introduced initially since 1970th in many cities around the world. It is estimated that over 70 cities decided to pilot or introduce free public transport already [8]. The most interesting European examples are two cities, namely Tallin and Hasselt, which brought significant experience to the whole knowledge on financing of free of charge public transportation system.

\section{THE EFECTS OF FREE PUBLIC TRANSPORT INTRODUCTION}

Free of charge public transportation system implementation leads both to positively and negatively perceived effects. This depends on the preconditions and goals initially set.

The most frequently noticed effect of free public transport implementation is an increase of number of public transport (PT) users. As a result of growing number of public transport 
users, traffic density in road system of the city decrease, while many former car drivers switch to free public transport [3]. This, however, may lead to increased density of passengers in public tarnsport, or may forse the local goverment to finance the additional lanes in existing transport system.

The other frequently mentioned effect is PT accessibility increase to all social groups, especially to those poorer who can not afford PT regular fares.

Another effects observed after introducing free PT are:

- transition of all transport costs on the local government budgets,

- cutting costs of tickets distribution and audit,

- decreasing PT unpunctuality caused by selling tickets by drivers on PT stops,

- increasing passengers space in PT busses, formerly used by ticketing systems [3].

\subsection{Chances and fears related to free PT implementation}

Local governments usually adapt the current PT offer when the current one is not sufficient. An increase of passengers number after free PT introduction may affect in both good and bad changes in transportation system of a city.

Free PT introdution should be couppled with an increase of PT offer, in order to adapt it to the growing number of users. This adaptation would prevent lovering the quality and comfort of passengers. High level of comfort, consequently, would bring more and more PT users from the group of car drivers quiting cars.

Less cars on streets would lead to decrease in envirnoment pollution, which would cause life quality increase.

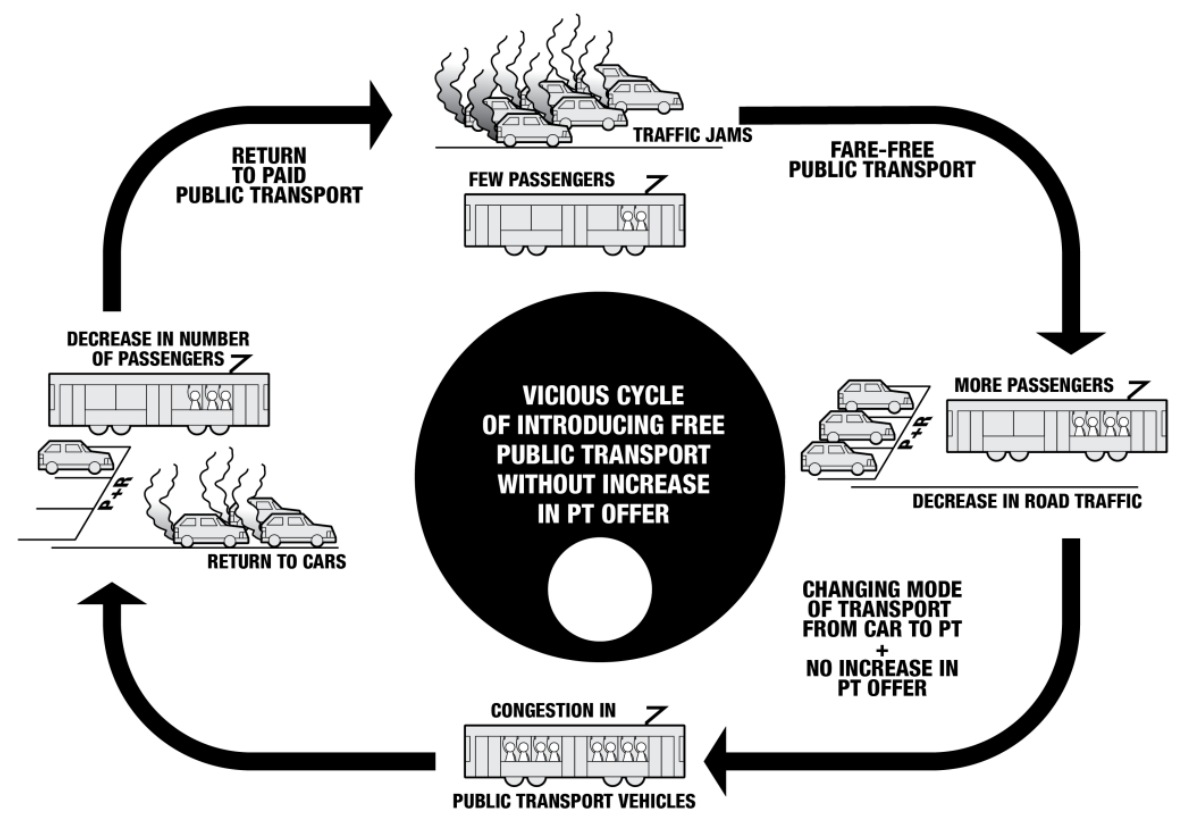

\section{Fig. 1 - Free PT vicious cycle}

When free PT introdution is not couppled with an increase of PT offer, both an increase of number of PT users and decrease of number of cars in the city are only short term effects, which is shown in case of Salt Lake City [3]. 
Without adaptation of existing PT to the increased demand of larger group of passengers, the vicious cicle appears soon (fig.1). No action and operation of local and regional authorities leads to a vicious circle of implementing free public transport (Mohring effect) with the introduction of the free PT the number of passengers is growing, as more drivers decide to leave their cars in the parking lot. Due to the lack of improvement of the transport offer appears piston in vehicles, public transport travel comfort falls and drivers are returning to their cars. Consequently, the city authorities observe lack of positive effects of the introduction of free PT and again lay down PT fares. The free PT vicious circle diagram is presented in Figure 1.

\subsection{Ways of improving transport offers}

Activities aimed at improving the offer of transport can be divided into permanent and provisional measures. Permanent measures are applied in case of cities where free collective transport journeys are introduced on a permanent basis, while provisional measures may be used when free rides are possible only in certain days or times of the day. Permanent activities aimed at improving the conditions of collective transport trip include, among others:

- fitting the existing public transport network to the changing demand for services,

- introduction of additional courses on the most loaded lines,

- organization of traffic with PT priorities,

- implementation of priorities for PT vehicles in traffic lights control systems.

To temporary measures belongs, among others:

- introduction of additional public transport lines and provide additional training courses on the lines that are running every day,

- temporary changes in the organization of traffic within cities to pass priority to urban public transport (as temporary bus lanes or parking erstrictions on narrow streets, with trams traffic),

- changes in traffic control systems in order to improve transit priority measures of public transport at intersections with traffic lights,

- organizing additional temporary Park and Ride car parks on multi-lane streets at the entrance to town (along with additional PT stops),

- informing residents about all changes and facilities during free access to urban services.

\section{EXAMPLES OF FREE PUBLIC TRANSPORT INTRODUCTION}

\subsection{Tallin Example}

Public Transport in Tallinn consists of 71 bus lines, 5 trolleybus lines and 4 tram lines [http://soiduplaan.tallinn.ee/\#tram-19.02.2016]. Access to free urban public transport was introduced on 1.01.2013 (only for residents of Tallinn). Since then it has been recorded 3\% (city-wide) increase in demand for public transport services, where $1.2 \%$ of increase is 
attributed to introduction of free travel, and the rest to improvement of transport offer. This increase was the most visible (even 11\%) in the neighborhoods of the city inhabited largely by the elderly, unemployed and non-motorised $[1,3]$.

Access to free PT services in Tallinn was preceded by many years of low ticket prices program, so that the increase in the number of passengers was gradual, which allowed introduction of solutions aimed at improving the offer of transport. Among the introduced solutions are worth mentioning: introduction of priorities in the road network for public transport and increasing the number of courses. Before introduction free PT for residents in the Estonian capital was $40 \%$ (30\%, 26\% by car) index of motorisation at 425 cars for 1000 inhabitants (2012. The monthly price of the ticket was $2.5 \%$ of the average monthly income of Tallinn citizens (after deducting fees for houses and other necessary expenses).

\subsection{Hasselt example}

The Belgian city of Hasselt introduced free public transport for residents (and on some lines also for tourists) in 1997. The introduction of free ridership has been preceded by a change in the offer of public transport. Running the new bus lines, increased the frequency of running existing priorities and for buses in the road network. Thanks to the implemented changes an increase in the number of passengers was reorded from 360 thousand per year (in 1996) to 4.6 million (in 2006) [9]. However, after 16 years, Hasselt abandonmed this solution. The reason for the abandonment of free PT was the increase in the cost of system maintenance. Due to the lack of sufficient financial resources, the city authorities have introduced amendments, according to which all citizens above 19 year old are obliged to pay [10].

\subsection{Examples of Polish cities}

Among Polish cities which have introduced free PT for residents are: Zory, NYSA, Zabki and Krakow. In Zory free access to transport services was provided for all residents, on all lines paid by the town. A similar solution is functioning in Zabki. In both cases, the changes in the way of free PT financing were dictated by a desire to raise the quality of life for residents and encourage them to use public transport [4]. The city of Nysa decided to introduce free travel for all residents. The offer was addressed exclusively to owners of cars which could show up a valid vehicle registration.

\subsection{Krakow example}

At the end of 2015 Krakow city has introduced free access to public transport services to residents within the Municipality of Krakow and neighbouring municipalities, in which operate bus lines (on the basis of an agreement). Free access to PT is only possible when air pollution standards are exceeded. Exceeding the acceptable standards of air condition is determined as follows:

- when the density of PM10 exceeds the level of 150 micrograms/m3 on each station,

- when the level of particulate pollutant concentrations of PM10 exceeds the level of 200 micrograms/m3 at one measurement stations [6,7]. 
According to Polish standards, mean concentration of PM10 particulate should not exceed 50 micrograms $/ \mathrm{m} 3$ in day time, and the permissible time-weighted average for the entire year is 40 micrograms/m3 [11]. Access to free travel when smog is possible only on presentation of proof of the registration of a passenger car. In addition, the download may travel well all potential passengers passenger car (their number specifies the vehicle registration certificate). Resolution of the Council of the city of Krakow that allows free PT was signed at the end of 2015 [6,7].

According to the President of Krakow, access to free urban collective transport services would be available from 0:00 to 24:00, next day after crossing the occupational concentration of PM10 particulate in the air. The decision is announced by telephone, Internet and other social media. After verifying the information on the state of air quality, the persons responsible for free public transport inform residents through the website of the transport managers (ZIKIT, Board of Municipal Infrastructure and Transportation) and social media (facebook m.in) and on the boards of the variable messanges on PT stops (Figure 2) and on monitors inside the urban public transport vehicles [7].

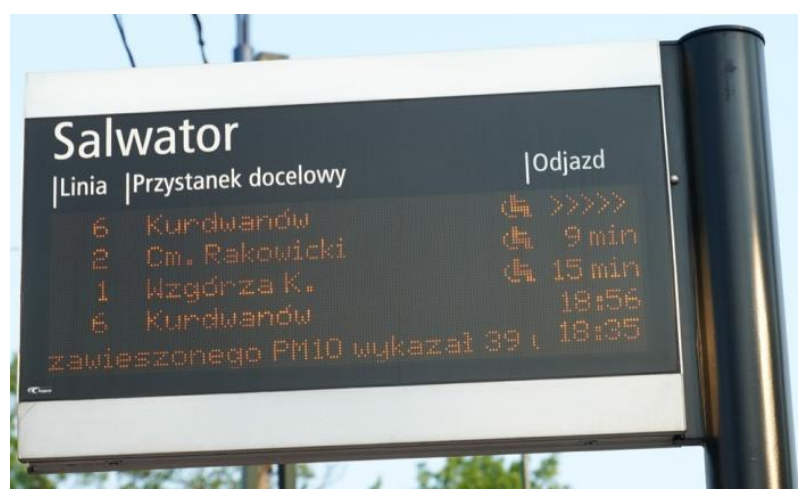

Fig. 2 - Variable message information table placed at tram stop in Krakow Source: http://d-nm.ppstatic.pl/k/r//26/b8/5649cbab1aff2_o.jpg?1447676920

The introduction of free PT exclusively for car owners, who are partly responsible for air pollution, is in contradiction with the principle of social equality. Passengers using public transport on a daily basis do not gain the right to free communication, by which this type of solution is not fair to all the inhabitants of Krakow and adjacent municipalities.

With an introduction of free PT in Krakow no decisions were taken to increase the seat number offer these days, in which the free rides will apply. As a result, you may overload the public transport system. Congestion of vehicles may ultimately lead to a situation in which the new user, despite free services, will not decide to change from car to public transport. Decision-making system based on measurements of average daily concentrations of PM10 particulate pollutant causes that free crossings on a given day may not reach all interested drivers, by what some of them do not benefit from free PT journeys.

\subsubsection{Proposals for changes in Kraków}

Among the previously mentioned ways of PT improvement, let us consider three ways that would apply. These solutions force temporary changes: 
- organization of traffic on streets within cities to pass measures of free PT,

- arranging additional temporary Park and Ride car parks on multi-lane streets,

- introduction of additional public transport lines and providing additional training courses on the new lines, every day.

The first of these solutions is the temporary change of traffic on part of the second ring road in Krakow (serial dual carriageways with three lanes in each direction) for the duration of the free collective transport journeys. The change would be exempted from one lane to traffic and convert it into a parking lot for cars and separation on the Middle Belt for buses and commuting vehicles to free parking (Figure 3).

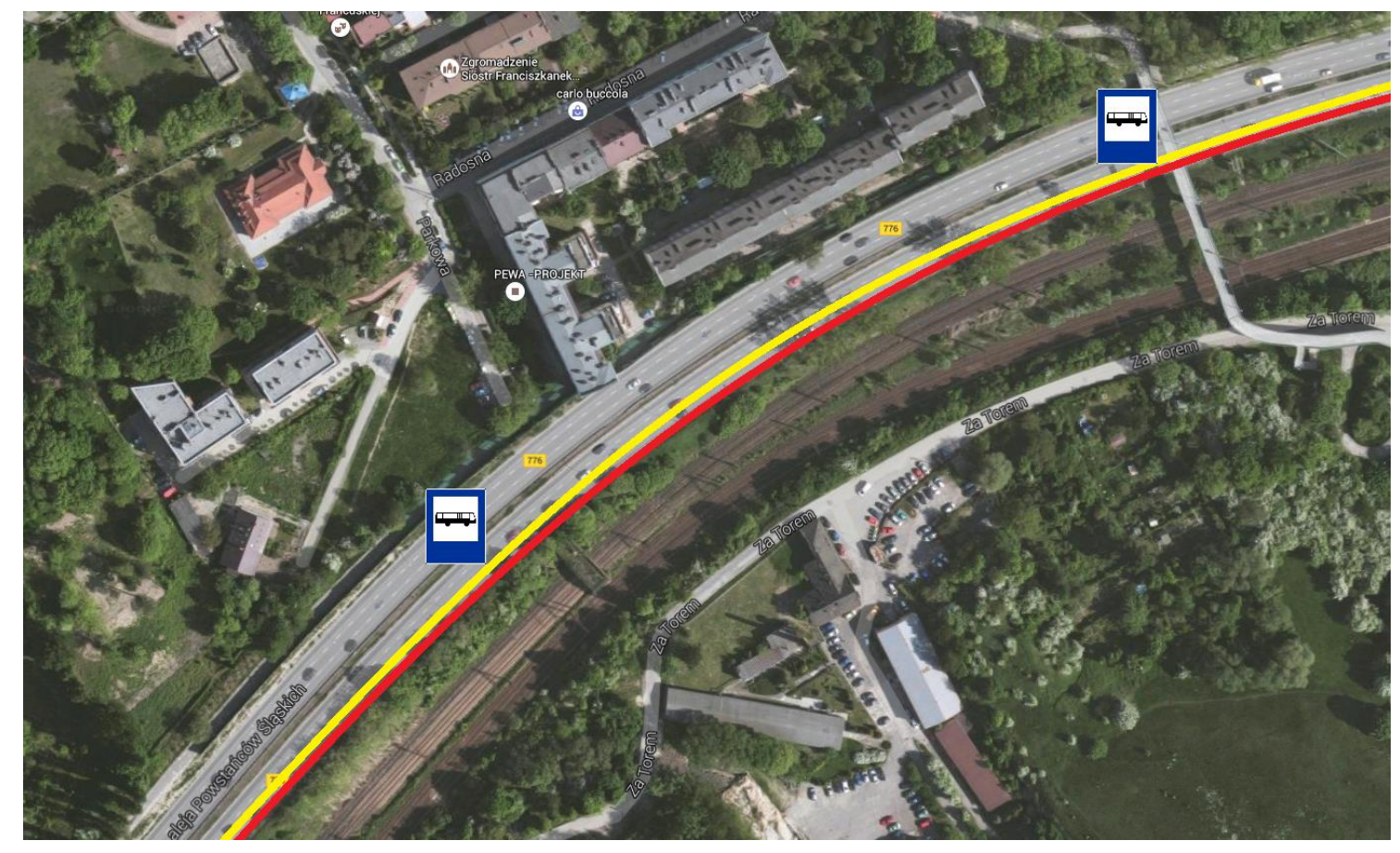

Fig. 3 Proposed change in traffic organization at II Krakow ring road

In order to examine the effects of the proposed changes, one segment was selected at the II Krakow ring road (crossing Tischnea Street, and the Silesian surgents' Avenue). To calculate time between PT stops for the adopted and for the current traffic, moderate congestion was regarded on the test road section [5].

The current model is used: (1)

$$
t^{r}=4.08 * l+0.13(s+z)
$$

where:

$\mathrm{t}^{\mathrm{r}}$ - average travel time between stops [min]

1 - length of test section $[\mathrm{km}]$

$\mathrm{s}-$ number of intersections with traffic lights

$\mathrm{z}$ - numbr of intersections without traffic lights, on which buses carry out subordinate relationships. 
Travel time variance was calculated using below formula:

$$
\sigma^{2}=1.29 * l
$$

For proposed change in organization of traffic, formula was assumed as in case of bus lane with maneuver permission for private vehicles (parking maneuvers on right side lane):

$$
t^{r}=2.87 * l+0.18 * s
$$

Variance for proposed changes was also calculated with different factor:

$$
\sigma^{2}=0.54 * l
$$

Analyzed section is 2.06 kilometer long, there are three intersections with traffic lights between bus stops. In current state calculated average time needed to pass that section with bus equals 8.8 minutes (variance is $2.7 \mathrm{~min}^{2}$ ), which corresponds to travel time survey during morning and afternoon rush hours conducted in 2014. Proposd changes in traffic organization can reduce average time to 6.45 minutes (variance $-1.1 \mathrm{~min}^{2}$ ), which is worth noting for more than 2 minute reduction in average travel time.

Due to reduction of travel time, additional bus stops could be placed along test section (for drivers parking on right side lane and boarding buses), which will increase public transport accessibility and would not significantly increase travel time on this section (average stop time was assumed as 17 seconds [4]).

On other streets, where there is no need for additional bus stops, shorter travel times will allow to launch extra runs on PT routes, maintaining the same maintenance cost (shorter travel times reduce need of PT vehicles, which can be moved to other routes).

This type of changes in traffic organization will lead to private vehicle traffic reduction in Krakow, which in following will reduce PM10 emission from road traffic. Additionally, temporary solutions in traffic engineering, will increase PT accsessibility, reduce travel times and maintain level of travel comfort.

\section{CONCLUSIONS}

Introduction of fare-free public transport, due to its many benefits can convince in short time share of drivers to use it in everyday transit (or in case of Krakow, in event of high air pollution). However this solution introduced without increasing PT offer, can lead to decrease in number of passangers in public transport and further decrease in PT offer (Free PT vicious cycle). To prevent this course of events, municipality deciding to introduce free PT, needs to increase number of courses, accsessibility and at the same time establish 
limitations for private cars, providing quick and comfortable means of switching to PT.

\section{REFERENCES}

[1] Cats O., Reimal T., Susilo Y., Public Transport Pricing Policy - Empirical Evidence from a Fare-Free Scheme in Tallinn, Estonia, 2014

[2] Grzelec K., Bezpłatna komunikacja miejska - cele oraz uwarunkowania jej wprowadzenia i funkcjonowania, Transport Miejski i Regionalny 4/2013

[3] Impacts of Free PT, Tallinn - Evaluation Framework, 2012

[4] Okraszewska R., Sierpiński G., Darmowy transport publiczny w Polsce uwarunkowania, bariery, doświadczenia, Logistyka 6/2014

[5] Praca zbiorowa pod redakcją A. Rudnickiego, Innowacje na rzecz zrównoważonego transportu miejskiego doświadczenia z realizacji projektu Unii Europejskiej CIVITASCARAVEL, Politechnika Krakowska, Wydział Inżynierii Lądowej, Instytut Inżynierii Drogowej i Kolejowej, Katedra Systemów Komunikacyjnych, Kraków 2010

[6] Uchwała NR XXXIV/578/15 Rady Miasta Krakowa

[7] Zarządzenie Nr 3628/2015 Prezydenta Miasta Krakowa z dnia 23/12/2015 r.

[8] Źródło internetowe: https://en.wikipedia.org/wiki/Free_public_transport - dostęp 19.02.2016

[9] Źródło internetowe: https://en.wikipedia.org/wiki/Hasselt - dostęp 19.02.2016

[10] Źródło internetowe: http://www.eltis.org/discover/news/hasselt-cancels-free-publictransport-after-16-years-belgium-0 - dostęp 19.02.2016

[11] Źródło internetowe: http://powietrze.gios.gov.pl/gios/site/content/annual_assessment_air_acceptable_level - dostęp 19.02.2016

- freepublictransports.com Network of groups promoting free public transport

- freepublictransit.org Advocacy website

- en.wordpress.com/tag/free-public-transport/ World Streets summer 2010 series on Free Public Transport

- Argument against free public transport 